Araştırma Makalesi • Research Article

\title{
Sağlık Yöneticisi Kavramına İlişkin Bir Metafor Analizi*
}

\section{A Metaphor Analysis to Related The Health Manager Concept}

\author{
Necla Yılmaz, ${ }^{\mathrm{a}, * *}$ Elif Özer, ${ }^{\mathrm{b}}$ Rabia Fettahoğlu ${ }^{\mathrm{c}}$ \\ ${ }^{a}$ Dr. Öğr. Üyesi, Süleyman Demirel Üniversitesi, İktisadi ve İdari Bilimler Fakültesi, Sağlık Yönetimi Bölümü, 32260 , Isparta/Türkiye. \\ ORCID:0000-0002-9847-6888 \\ b Süleyman Demirel Üniversitesi, Sosyal Bilimler Enstitüsü, Sağlık Yönetimi Bölümü, 32260, Isparta/Türkiye. \\ ORCID:0000-0002-3745-2399 \\ c Öğr. Gör., Süleyman Demirel Üniversitesi, Sosyal Bilimler Enstitüsü, Sağlık Yönetimi Bölümü, 32260, Isparta/Türkiye. \\ ORCID:0000-0002-5736-7175
}

\section{MAKALE BİLGİṠ \\ Makale Geçmişi: \\ Başvuru tarihi: 02 Ocak 2019 \\ Düzeltme tarihi: 16 Temmuz2019 \\ Kabul tarihi: 23 Ağustos 2019}

Anahtar Kelimeler:

Sağlık yöneticisi,

Sağlık yönetimi,

Sağlık yönetimi öğrencileri,

Metafor analizi,

Nitel araştırma

\section{A R T I C LE INFO}

Article history:

Received: 02 January 2019

Received in revised form: 16 July 2019

Accepted: 23 August 2019

\section{Keywords:}

Health manager,

Health management,

Health management students,

Metaphor analysis,

Qualitative research
ÖZ

Bu çalışmanın amacı, Sağlık Yönetimi Bölümü öğrencilerinin sağlık yöneticisine ilişkin algılarının metaforlar aracılığıyla tespit edilmesidir. Bu amaca yönelik olarak çalışmada nitel araştırma yöntemi tercih edilmiş olup, fenomenoloji (olgu bilim) deseninden yararlanılmıştır. Araştırmanın çalışma grubunu Süleyman Demirel Üniversitesi İIBB Sağlik Yönetimi Bölümü’nde öğrenim gören 276 sağlık yöneticisi adayı oluşturmaktadır. Katılımcılardan "Sağlık yöneticisi .............. gibidir; çünkü ..........." şeklinde soru ile veriler elde edilmiştir. Metaforların analizi ve yorumlanması; adlandırma, eleme ve arıtma, derleme ve kategori geliştirme, geçerlik ve güvenirliği sağlama ile verileri bilgisayar ortamına aktarma olarak beş aşamada gerçekleşmiş ve veriler içerik analizi kullanılarak incelenmiştir. Araştırma sonucunda üretilen metaforlar; yönetsel unsurlar, yönetici nitelikleri, hayati öneme sahip olması, liderlik özellikleri taşıması, çok yönlü olması, sağladığı fayda, mesleğin algılanan olumsuzlukları ve meslekteki konumu bakımından şeklinde 8 farklı kategori kapsamında ele alınmıştır.

\section{A B S TR ACT}

The aim of this study is to determine the perceptions of students of the Health Management Department about the health manager through metaphors. For this purpose, qualitative research method was preferred in the study and phenomenology (phenomenology) pattern was used. The study group of the study consists of 276 candidates for health administrators studying at Süleyman Demirel University FEAS Health Management Department. From the participants, "Health manager is like ............; because .......... "question has been obtained with data. Analysis and interpretation of metaphors; naming, screening and refining, compilation and category development, ensuring validity and reliability, and transferring data to the computer environment took place in five stages and the data were analyzed using content analysis. Metaphors produced as a result of the research; managerial elements, manager qualifications, vital importance, leadership features, versatility, benefits provided, perceived negativities of the profession and position in the profession are covered in 8 different categories.

\section{Giriș}

Dünya koşullarının değişmesi neticesinde insanların ihtiyaç ve beklentilerinde dönüşümler yaşanmıştır.
Toplumsallaşmayla beraber insanlar sürekli iletişim halinde olmaya başlamıştır. Ortaya çıkan değişimler neticesinde hizmet işletmelerine olan önem artmıştır. Hizmet işletmeleri adına en fazla öneme sahip alan ise, sağlık hizmetleri olarak

* Bu çalışma, 11-13 Ekim 2018 tarihlerinde Muğla'da düzenlenen 2. Uluslararası 12. Ulusal Sağlık ve Hastane İdaresi Kongresi’nde bildiri olarak sunulmuştur.

** Sorumlu yazar/Corresponding author

e-posta: neclabardak@sdu.edu.tr 
ele alınmaktadır. Bu anlamda öne çıkan kuruluşlar ise sağlık kuruluşları olarak ifade edilmektedir. Sağlık kuruluşlarında verilen hizmetin yapısı gereği farklı disiplinlerin bir araya gelmesi nedeniyle hatayı kabul etmeyen bir özellik taşımaktadır. Sağlık kurumları adına hizmetin etkili ve verimli olması için de planlama, örgütleme, yöneltme ve kontrol işlevlerinin doğru şekilde bir araya gelmesini sağlayacak profesyonel yöneticilere gereksinim duyulmaktadır. Ülkemizde sağlık hizmetlerinin sunumu bakımından hem sosyal politikalar hem de sağlık alanında yaşanan gelişmeler neticesinde Cumhuriyet'in ilk günlerinden bu yana belli değişimimler yaşanmıştır. 1980 ile 2000 yılları arasında Dünya Bankası gibi kuruluşların desteğinin alınması nedeniyle hizmet sunumundan finansmana kadar her alanda desteklenen projelerler neticesinde, üniversitelerde sağlık yönetimi ve sağlık yönetimi işletmeciliği bölümleri açılmış ve yaygınlık kazanmaya başlamıştır. (Öztürk ve Ilıman, 2015: 73; Ayanoğlu vd., 2013: 2). Konuya bu açıdan bakıldığında, sağlık hizmeti sunumunda görev alan yöneticilerin alanla ilgili bilgi sahibi olmasının yanı sıra çağın gereklerine uygun hareket etmesi önem arz edebilir. Sağlık yöneticileri, sağlık hizmetlerinde var olan mevcut sorunların üzerine giderek çağdaş yönetim tekniklerini kendi sağlık sistemleriyle entegre bir şekilde yürütebilir; ekonomi, hukuk, finansman, kalite yönetimi ve pazarlama gibi alanının önemli konularına dair eğitim almış olmaları önemli görülmektedir.

Özellikle gelişmiş ülkelerde, II. Dünya Savaşı sonrasında bilimsel bilgi birikiminin artmasıyla birlikte, birçok üniversitede sağlık yönetimi üzerine eğitim verilmeye başlanmıştır. Sağlık yönetimi, sağlık hizmetleri yönetimi ve sağlık kurumları yönetimi lisans ve lisansüstü programları kendi eğitim bünyelerinde aktif hale getirilmiştir. Ülkemizde ilk olarak, 1963'te "Sağlık İdaresi" ismi ile bu alanda lisans düzeyinde eğitim verilmeye başlanmıştır. Zaman geçmesiyle beraber bölüm daha yaygın bir hal almıştır (Öztürk ve Ilıman, 2015: 73; Çimen, 2010: 137).

YÖK 2018 verilerine göre, ülkemizde sağlık yönetimi adı altında 26 devlet, 23 özel ve 1 açık öğretim programı kapsamında eğitim verilmektedir. Bunun yanı sıra sağlık kurumları işletmeciliği adı altında; 32 devlet, 20 özel ve 3 açık öğretim programında eğitim verilmektedir (YÖK Lisans Atlası ve YÖK Ön Lisans Atlası, 2018).

Mesleki eğitim alan insanların yanı sıra hizmet sunumunda yer alanların mesleğe ilişkin algılarını ortaya koymak adına metaforun kullanıldığı bilinmektedir. Cerit (2008: 694) metafor kavramını; hayatı, çevreyi, olayları ve nesneleri insanların nasıl algıladıklarını ortaya koymak için farklı benzetmelerin kullanılmasında bir araç olarak ele almıştır. İngilizce bir kelime olan metafor (metaphor) Türkçe'de "benzetme, eğretileme" manasına gelirken Eski Türkçe'de "mecaz" ve Arapça'da “istiare” kelimelerine denk gelmektedir. Bir şeyi ya da bir fikri ifade etmek için benzer kavramları gibi ve benzer kelimelerini kullanmadan tanımlama yapmak olarak ifade edilmiştir. Bir kavramı, kelimeyi, terimi daha güzel anlatmak adına kullanılan bir araç olarak ele alınmaktadır (Aydın, 2006: 10).

Kavramlar algılanırken genel olarak diğer kavramlarla ortak yönlerinin kullanılması yöntemine başvurulmaktadır. Bir kavram yeni öğreniliyorsa, yaygın olarak bilinen diğer durumların özellikleriyle eşleştirilmekte veya zihinde benzetme yapılarak bir bağ kurulmaktadır. Bu bağlamda metaforlar sayesinde anlaşılmasında güçlük yaşanan kavramlar bilenen kavramlara benzetilerek formal ve informal anlamda öğrenme gerçekleşmektedir (Geçit ve Gençer, 2011: 2).

Metafor; "kavramsal algıları yansitan ifadeler" olarak ele alınabilirken, insanların yaşamlarını, çevrelerini ve çevrede olup biten olayları açıklamasına yardımcı olmaktadır (Akan vd., 2014: 169). Yine metafor kavram1, "kelimelerin bir araya gelerek çağrışım yapması işlemi" olarak ifade edilebilir. Bu sayede bir kavrama ilişkin tanımın zihinde nasıl kurgulandığ 1 ortaya konabilir.

Stierand ve diğerleri (2016: 2) metaforu karakterlerin, yaratıcılığın ve oyunun gerçekleştiği girişimsel alan olarak ifade ederken Lakoff ve Johnson (2003: 8) ise pek çok insan açısından şiirsel hayal gücü ve retorik gelişmenin bir sonucu olarak ele almıştır. Düşünce ve eylemlerden ziyade kelimelerin kullanımı sayesinde özellik kazanmaktadır. Bundan ötürü metaforun günlük hayatta kullanımı oldukça yaygınlık göstermektedir.

Metafor, bir kavram veya terimin belirli bir benzerliği ifade etmek amacıyla farklı bir içeriğe uygulandığ formudur. Metaforlar, kullanım olarak genellikle dil ve felsefe alanına daha yakın gibi gözükse de, 1980'lerden sonra farklı yönleriyle kullanılmaya başlanmış olup, özellikle Lakoff ve Johnson'un 'Metafor We Live By' çalışması ile birlikte bilişsel bir kimlik kazanmıştır. Yalnızca felsefe ve dil alanı ile sınırlandırılamayacak kadar genişleyen metafor kullanımı, başta eğitim bilimleri olmak üzere sosyal bilimler alanında da varlığını sıklıkla göstermektedir. Deneyimli bir gerçeği, duygusal içe aktarımın yanı sıra, söylemsel içeriğe sahip algılanabilir bir nesneye dönüştürür ve kalite, nesneyi üreten yaratıcının hayal gücü ve duygusal tepkiden ayrılan bir yapıda ele alınmamaktadır. Hem fiziksel fenomenlerin nesnelliği hem de insan duyarlılığının öznelliği, içten bir tutku eylemiyle kaynaştırılmaktadır. Kısacası metafor; rasyonel söylem veya duygusal söylemin ötesinde indirgenemeyecek bir anlam taşımaktadır (Hogler vd., 2008: 394). Wittink (2011: 2), dil kullanımında soyut kavramların öneminden bahsederek, metaforların insanların deneyimlerini incelemenin bir yolunu sağladığını belirtmektedir. Jensen'a (2006: 40) göre metaforlar tanıdık bir kavramla ilgisi bulunan bir bilgiyi benzer bir konsepte bağlamakta ve bu karşılaştırma sürecinde yeni bir anlayış ortaya çıkmaktadır. Nikinitina ve Furuoka'ya (2008: 194) göre metaforlar, insanların gerçek dünya fenomeninin kendi zihinsel imgeleriyle gerçeği filtrelemelerinde bir araç görevi görmektedir.

Sağlık yöneticileri ile ilgili literatürde yer alan araștırmalara bakıldığında oldukça fazla çalışmanın olduğu görülmektedir (Şener vd., 2010; Bulut ve İşman, 2004; Öztürk vd., 2008; Karsavuran, 2014a; Aslan ve Özata, 2006; Bostan vd., 2012; Kahyaoğlu vd., 2013; Karsavuran, 2014b). Literatürde özellikle öğretmenlik mesleğiyle ilgili metaforik çalışmaların (Saban vd., 2007; Koç, 2013; Çetinkaya, 2014; Dös, 2010; Güveli vd., 2011; Tortop, 2013; Saban, 2009; Altun ve Camadan, 2013) yer aldığı tespit edilmiştir. Bunun yanı sıra hekim, hemşire ve hastaların örneklem grubu olarak tercih edildiği ve metafor analizinin kullanıldığ da rastlanmıştır (Sairanen, 2015; Kale ve Çiçek; Casarett, 2010). Daha kapsamlı olarak sağlık çalışanlarının mesleklerini nasıl algılandıklarını metafor analiziyle ortaya koyan Bozkurt ( 2012)'un yüksek lisans tezi bulunmaktadır. 
Kanser hastalığıyla ilgili yapılan metafor analizi çalışmaları (Levitt vd., 2000; Krieger vd., 2014; Magaña ve Matlock 2018) da literatürde oldukça fazla yer kaplamaktadır. Hastanelerdeki görevlerin daha iyi anlaşılabilmesi amacıyla yöneticiler üzerinden yürütülen bir metafor analizi çalışması da yer almaktadır (Woodside, 2017). Yapılan literatür incelmesi sonucunda, sağlık yöneticisi adaylarının mesleklerine yönelik algılarını ortaya koyan herhangi bir çalışmanın olmadığı görülmüştür. Metafor analizinden yararlanılarak yapılacak olan bu çalışma neticesinde, sağlık yöneticisi adayı olan öğrencilerin "sağlık yöneticisi” algısı ortaya konulacaktır.

\section{Araştırmanın Yöntemi}

\subsection{Araştırmanın Amacı ve Yöntemi}

$\mathrm{Bu}$ araştırmanın amacı, Sağlık Yönetimi Bölümünde öğrenim gören öğrencilerin "sağlık yöneticisi” kavramına ilişkin algılarını metaforlar aracılığıyla belirlemektir. Öğrencilerin "sağlık yöneticisi" hakkında ne tür metafor oluşturdukları ve oluşturulan metaforların ortak özellikleri açısından hangi kategoriler altında toplandığını amaçlayan bu çalışma, nitel araştırma yöntemi ile kurgulanmıştır. Çalışma ayrıca, "sağlık yöneticisi”" olgusunun derinlemesine araştırılmasına imkân tanıyan fenomenoloji (olgu bilim) deseni ile yürütülmüştür. Fenomenoloji; daha çok insanın iç dünyasını ve onların bilinç yapılarını anlamaya çalışan bir araştırma desenidir (Mayring, 2011: 110). Bu araştırma deseninde, daha çok deneyimlere ve yaşanmışlıklara odaklanılmaktadır (Polkinghorne, 1989: 45). Nitel bir araştırma sürecinde olgu ve kavramları incelemek amacıyla kullanılan metafor analizi, konuyla ilgili dilsel metafor örneklerini toplamak, bunları kavramsal metaforlarla genelleştirmek ve bunları oluşturan anlayışların veya düşünce kalıplarının ortaya konması için kullanılan bir yöntemdir. Metafor analizinin amacı, katılımcıların sistematik olarak birbirleriyle bağlantılı olduklarını düşündükleri dilsel ifadelerin analizi yoluyla bir kavramı diğeriyle ilişkilendirmesini sağlayan sosyo-bilişsel bağlantılardan oluşan kavramsal metaforları anlamaya çalışmaktır (Armstrong vd., 2011: 1). Ayrıca karmaşık kavram, olay ve olguların derinlemesine araştırılmasında etkili bir yöntem olan metafor analizi önemli bir nitel araştırma yöntemi olarak görülmektedir (Güneş ve Fırat, 2016: 125).

\subsection{Araştırmanın Katılımcıları}

Bu araştırma, 2017-2018 eğitim-öğretim yılının güz ve bahar döneminde Süleyman Demirel Üniversitesi İktisadi ve İdari Bilimler Fakültesi Sağlık Yönetimi Bölümünde 1., 2., 3., ve 4.sınıfta öğrenim gören toplam 276 öğrencinin katılımıyla yürütülmüştür.

Tablo 1. Katılımcıların Cinsiyete Göre Dağılımları

\begin{tabular}{lll}
\hline Cinsiyet & Frekans & Yüzde \\
\hline Kadın & 192 & 69.6 \\
\hline Erkek & 84 & 30.4 \\
Toplam & 276 & 100.0 \\
\hline
\end{tabular}

Tablo 1'de görüleceği üzere, katılımcıların \%69.6'lık kısmı kadın iken, \%30.4'lük kısmı erkektir.
Tablo 2. Katılımcıların Sınıf Düzeylerine Göre Dağılımları

\begin{tabular}{lll}
\hline Sınıf & Frekans & Yüzde \\
\hline 1. Sinıf & 60 & 21.7 \\
2. Sinıf & 77 & 27.9 \\
3. Sınıf & 79 & 28.7 \\
4. Sınıf & 60 & 21.7 \\
Toplam & 276 & 100.0 \\
\hline
\end{tabular}

Tablo 2 incelendiğinde, tüm sınıf düzeylerinde \%20'nin üzerinde bir katılımın gerçekleştiği görülmektedir. En fazla katılım gösteren sınıf düzeyi ise \%28.7'lik bir kısımla 3. sınıf olmuştur.

\subsection{Verilerin Toplanmasi}

Araştırmaya katılan sağlık yönetimi bölümü öğrencilerine, "sağlık yöneticisi” kavramına yönelik algının ortaya çıkarılması amacıyla öncelikle metaforun ne olduğu farklı kavramlar üzerinden açıklanmış ve sonrasında "Sağlık yöneticisi ............ gibidir. Çünkü ............." ifadesinin yer aldığı yarı yapılandırılmış formlar dağıtılarak boş olan kısımları doldurmaları istenmiştir. Ayrıca sağlık yöneticisine ilişkin benzetmeleri yalnızca tek bir varlığa benzetebilecekleri ve çünkü ile başlayan ifadenin benzetmeyi açıklayıcı nitelikte olması gerektiğine dikkat etmeleri vurgulanmıştır. Araştırmacı öğrencilerin ders saatlerinde gönüllük esasına dayanarak öğrencilerden "sağlık yöneticisi" kavramına ilişkin kendi metaforlarını yazmalarını istemiş ve doldurulan formlar araştırmacı tarafından toplanmıştır. Aynı zamanda öğrencilerden formda yazılı olan cinsiyet ve sınıf ifadelerini de işaretleyerek belirtmeleri istenmiştir. Öğrencilerin yazdıkları metaforlar, araştırmanın temel veri kaynağını oluşturmuştur.

\subsection{Verilerin Analizi ve Yorumlanma Süreci}

Araştırma kapsamında elde edilen verilerin incelenmesi amaciyla nitel analiz tekniklerinden biri olan içerik analizi kullanılmıştır. Saban'ın (2008: 424) ele aldığı şekliyle metafor; X olgusunun Y olgusu gibi olduğunu açık ya da örtük bir biçimde belirtilmesiyle ortaya çıkmaktadır. Metaforu güçlü kılan olgu ise iki benzer olmayan kavram arasında bir bağ kurması sayesinde olmaktadır. Araştırmaya başlanmadan evvel, daha önce bu konu üzerine yapılan çalışmalar (Altun ve Camadan, 2013; Aydın, 2006; Cerit, 2008; Saban, 2008) incelenmiştir. Bu konuda yapılmış çalışmalarda, metaforların analizi ve yorumlanması beş aşamada gerçekleşmektedir. Bu aşamalar şu şekildedir;

- Adlandırma Aşaması,

- Eleme ve Arıtma Aşaması,

- Derleme ve Kategori Geliştirme Aşaması,

- Geçerlik ve Güvenirliği Sağlama Aşaması

- Verileri Bilgisayar Ortamına Aktarma Aşaması

$\mathrm{Bu}$ çalışma kapsamında üstte geçen aşamalar sırasıyla izlenmiş ve sağlık yöneticisinin nasıl algılandığına ilişkin ortaya konan metaforların analizi ve yorumlaması aşağıdaki başlıklar altında gerçekleşmiştir.

2.4.1. Adlandırma Aşamast: $\mathrm{Bu}$ aşamada öncelikle araştırmaya katılan öğrenciler tarafindan doldurulan formların her birine bir numara verilmiştir. $\mathrm{Bu}$ amaçla öğrencilerin ifadelerinde metaforların net bir şekilde dile 
getirilip getirilmediği anlaşılmaya çalışılmış ve her öğrencinin sunduğu formda ifade edilen metaforlar kodlanmıştır (örneğin; aslan, su, ağaç, bina temeli vb.). Herhangi bir metaforun ifade edilmediği formlar ise işaretlenmiştir.

2.4.2. Tasnif Etme (Eleme ve Arttma) Aşaması: Bu aşamada öğrencilerin yazdıkları metaforlar "içerik analizi" vasıtasıyla parçalara ayrılmış ve tek tek okunup gözden geçirilmiştir.

Her bir metafor; (a) metaforun konusu, (b) metaforun kaynağı ve (c) metaforun konusu ile metaforun kaynağ1 arasındaki ilişki bakımından analiz edilmiştir. Tüm öğrencilerin geçerli metafor üretemedikleri görülmüştür. Herhangi bir metafor kaynağını içermemesi, herhangi bir gerekçenin ya da mantıksal dayanağın sunulmaması, birden fazla kategoriye ait özellikler içermesi, mantıksız veya sağlık yöneticisi kavramının anlaşılmasına herhangi bir katkısı olmaması nedeniyle toplam 35 form araştırma kapsamı dışında bırakılmıştır. Söz konusu 35 metaforun Altun ve Camadan'ın çalışmasında yer alan "zayıf metafor" kavramı altında ele alınmasının uygun olacağı düşünülerek, (2013: 889) zayıf metaforlar dört ana başlık altında toplanmıştır:

a) Metafor kaynaklarından birini içermemesi: $\mathrm{Bu}$ ölçütün öne alınması neticesinde 5 adet metafor elenmiştir. Bunlardan biri şu şekildedir; Sağlık yöneticisi meyve bahçesi gibidir; çünkü bütün meyvelere aynı bakımı gösterirsin ama hepsi birbirinden farklı olur. Kimi iyi kimisi kötü (Katılımc1, 136, K).

b) Benzetme yapılırken arada bir gerekçenin kurulamaması: $\mathrm{Bu}$ ölçüt altında ise 13 adet metafor elenmiştir. Bunlardan bir tanesi şu şekildedir; Sağlık yöneticisi güllaç gibidir; çünkü istediğinde ulaşamazsın (Katılımcı, $112, \mathrm{~K})$.

c) Özellikleri bakımından birden fazla kategoriye ait olması: $\mathrm{Bu}$ bakımdan ele alınan sonuçlar itibariyle 13 metafor elenmiştir. Bir tanesi ise şu şekildedir; Sağlık yöneticisi midye gibidir; çünkü denizde bir dünya vardır ancak içinden elmas çıkma ihtimali de vardır (Katılımcı, 195, $\mathrm{K})$.

d) Sağlık yöneticisinin anlaşılmasında mantıklı bir açıklama sunmaması: $\mathrm{Bu}$ bakımdan ele alınan metaforlardan 4 tanesi elenmiştir. Bunlardan bir tanesi ise şu şekildedir; Sağlık yöneticisi yeni gelin gibidir; çünkü heyecanlı ve her an ataktadır (Katılımc1, 14, K).

Yukarıda geçen gerekçelerden ötürü toplam 35 form kapsam dışı kalmıştır. Katılımcıların zayıf metaforlarının elenmesi neticesinde 241 adet geçerli metafor elde edilmiştir. Geriye kalan metaforlar ise, gözden geçirilmiş ve Adlandırma Aşamasında ortaya çıkan tablo tekrardan düzenlenmiştir.

\subsubsection{Derleme ve Kategori Geliştirme Aşaması: Bu} aşamada, katılımcılar tarafindan üretilen metafor imgeleri sağlık yöneticisi kavramına ilişkin sahip oldukları ortak özellikler bakımından değerlendirilmiştir. Katılımcılar tarafindan üretilen her metafor, sağlık yöneticisi kavramını yansıttığı düşünülen ve metaforların ortak özelliklerine göre belli bir tema ile ilişkilendirilerek, toplam 8 farklı kavramsal kategori oluşturulmuştur. Bunlardan bir tanesi "yönetsel unsurlar bakımından sağlık yöneticisi" olarak ele alınmıştır.
$\mathrm{Bu}$ kategoride yer alan metaforların sağlık yöneticisinin; yönetim fonksiyonunun yanı sıra planlama, kontrol etme, yol ve yön gösterme, sorumluluk sahibi olma, karar verebilme ve koordinasyon gibi yönetim konusunun asli ve önemli unsurlarına sahip olabilme gerekliliği gibi ortak özellikleri içermesini barındırmaktadır. Bir diğer kategori ise; "hayati öneme sahip olması bakımından sağlık yöneticisi”, kategorisidir. Bu kategorinin altında yer alan metaforların hepsi, temelde sağlık yöneticisini hastaneyi ayakta tutan kişi ve hastane için olmazsa olmaz bir unsur olarak değerlendirmektedir. $\mathrm{Bu}$ kategorinin altında yer alan metaforlardan bir tanesi "su" metaforudur. İfade ise şu şekildedir: "Sağlık yöneticisi su gibidir. Çünkü vücudumuzun her daim suya ihtiyacı olduğu gibi hastanenin de her daim sağlı yöneticisine ihtiyacı vardır."

2.4.4. Geçerliliği ve Güvenilirliği Să̆lama Aşaması: Araştırma neticesinde Saban'ın (2009) değindiği üzere, metafor çalışmalarının geçerliliğini kabul görmesi bakımında iki ölçüte yer verilmiştir. Bu ölçütler ise; (1) veri analizi sürecinin kapsamlı bir şekilde ele alınması (2) bulguların işlenmesi ve yorumlanması bakımından katılımcılara ait olan metafor ifadelerinin veri kaynağı bakımından temel olarak baz alınmasına önem verilmesi şeklinde ifade edilmiştir.

Nitel bir araştırmada elde edilen verilerin ayrıntılı bir şekilde rapor edilmesi ve araştırmacının sonuçlara nasıl ulaştığını açıklaması geçerliliğin önemli ölçütleri arasında bulunmaktadır (Yıldırım, 2010: 81-82). Bu bağlamda, araştırmada kullanılan yöntemlerin ve desenin neden kullanıldığının gerekçesi, çalışma grubunun özellikleri, verilerin nasıl toplandığı, verilerin nasıl analiz edilip yorumlandığı açık ve ayrıntılı bir şekilde ortaya konulmaya çalışılmıştır. Araştırmanın güvenilirliği sağlamak amacıyla ise araştırmada ulaşılan 8 farklı kavramsal kategori içinde yer alan metaforların, söz konusu bir kavramsal kategoriyi temsil edip etmediğini teyit etmek amaciyla uzman görüşüne başvurulmuştur. Uzman görüşü alınan araştırmacılar; nitel araştırma konusunda daha evvel çalışmaları bulunan ve Sosyal Bilimler alanında çalışma yapan 3 akademisyenden oluşmaktadır. Bu kapsamda uzman araştırmacılara iki liste verilmiştir. Verilen listelerden birinci liste öğrencilerin ifade ettikleri metaforların olduğu, ikinci liste ise, kavramsal kategorilerin isimlerini ve özelliklerini içeren bir listedir. Uzmanların her birinden, bu iki listeyi kullanarak birinci listedeki metaforları ikinci listedeki kavramsal kategorilerle eşleştirmesi istenmiştir. Daha sonra araştırma sürecinde yapılan kategorileştirme ile uzmanın yaptı̆̆ı kategorileşme sonuçları karşılaştırılmıştır.

Araştırmanın güvenilirliğini elde etmek amacı ile metafor analizi kullanılan çalışmalardan (Altun ve Camadan, 2013; Aydın, 2006; Cerit, 2008; Saban, 2008) yararlanılmıştır. Neticede, araştırmanın güvenilirliğinin elde edilmesinde üretilen metaforlar toplamda 8 kategori altında ele alınmış ve bu kategorilerin uygun olup olmadığı ile ilgili uzman görüşü alınmıştır. Bu görüşler neticesinde 8 kategori dışında kalan metafor ifadeleri tasnif etme aşamasında ele alınmıştır.

\subsubsection{Verilerin Bilgisayar Ortamına Aktarllması:} Katılımcıların cinsiyetleri ve öğrenim gördükleri sınıf düzeylerini de ele alan çalışma toplamda 241 metafor ifadesini ortaya koymuştur. $\mathrm{Bu}$ kategorilerin SPSS programına aktarılarak analizi sağlanmıştır. $\mathrm{Bu}$ sayede 
katılımcılara ait olan özellikler ve metaforlar ortaya konan kategoriler ile (f) ve yüzde (\%) şeklinde değerleri ortaya konmuştur.

\section{Bulgular}

$\mathrm{Bu}$ bölümde araştırma kapsamında Sağlık Yönetimi öğrencilerini, "sağlı yöneticisi” kavramına yönelik geliştirdikleri metaforlara ilişkin bulgular sunulmuştur.

Tablo 3. Kategori ve Metaforlara Ait Bulgular
Katılımcıların ürettikleri metafor ifadeleri incelendiğinde, bu metaforların ortak özellikleri bakımından 8 adet farklı kavramsal kategori altında toplanabildiği görülmüştür. $\mathrm{Bu}$ kategoriler; Yönetsel Unsurlar, Yönetici Nitelikleri, Hayati Öneme Sahip Olması, Liderlik Özellikleri Taşıması, Çok Yönlü Olması, Sağladığı Fayda, Mesleğin Algılanan Olumsuzlukları ve Meslekteki Konumu Bakımından şeklindedir.

\section{Frekans Metafor}

Adedi

\begin{tabular}{|c|c|c|c|}
\hline $\begin{array}{l}\text { Mesleğin Algılanan } \\
\text { Olumsuzlukları }\end{array}$ & $\begin{array}{l}\text { Çamaşır makinesi (1), Yokuş (1), Uçak (1), Pırasa yemeği (1), Boş teneke (1), } \\
\text { Tarih (1), Apandis (1), Çürük karpuz (1), Beyaz pastel boya (1), Karadelik (1), } \\
\text { Balık (1), Dilekçe (1), Kapatılmış tren garı (1), Ceviz (1), Görünmez kahraman } \\
\text { (1), Deniz (1), Dolaba konmayı unutulan, meyve (1), Gözleri görmeyen bir insan } \\
\text { (1), İşsiz (3), Limon (1), Hamal (1), Dolar (1), Ruhsal güçler (1), Erişilmesi zor } \\
\text { bir ufuk (1), Hayal (1), Halı (1), Mum (1), Tuz (1), Kitap (1), Ofsayt (1), Kenarda } \\
\text { duran vazo (1), Greyfurt (1), Hiçbir şey (1), Bıçak (1), Amele (2), Karanlık (1), } \\
\text { Tuvalet kağıdı (1), Çıkmaz yol (1), Türkiye (1), Meyve vermeyen ağaç (1), Cıvık } \\
\text { hamur (1), Ayakkabı (1), Marka (1), Ekşi sakız (1) }\end{array}$ & 47 & 44 \\
\hline Meslekteki Konumu & $\begin{array}{l}\text { Yeşillik (1), Paslı bir demir (1), Bebek (1), Evin kapısı (1), Kalp (1), Akraba } \\
\text { evliliği (1), Bor (1), Geniş bir ailenin babası (1), İzmir Halkapınar metro } \\
\text { istasyonu (1), Çölde yağan kar (1), Gezegen (1), Milyonluk bir eşya (1), } \\
\text { Etkileyici film (1), Ağaç (1), Şarap (1), Beton (1), Mutfak robotu (1), Hastane } \\
\text { (1), Fidan (1), Güneş (1), Kömür (1), Atanamayan öğretmen (1), Bal peteği (1), } \\
\text { Midye (1), Türkiye (1), Gülün dikeni (1), Altın (1), Dolar (1), Domates (1), } \\
\text { Makyaj bazı (1), Engeli olan bir yol (1), Umut (1), İnci (1), Kelaynak (1), } \\
\text { Oyuncak (1) }\end{array}$ & 35 & 35 \\
\hline $\begin{array}{l}\text { Hayati Öneme Sahip } \\
\text { Olması }\end{array}$ & $\begin{array}{l}\text { Fidana hayat veren can suyu (1), Hastanenin direği (1), Yemek (2), Binanın kaba } \\
\text { inşaatı (1), Çay (1), Ağaç kökü (2), Beton (1), Omurga (1), Buğday (1), Arabanın } \\
\text { motoru (1), Sağlik (1), Hayat kurtaran (1), Su (8), Maden (1), Ağaç (1), } \\
\text { Hastanenin kolonu (1), Puzzle parçası (1), Cankurtaran (1), İskelet (1), Direk (1), } \\
\text { Yağ (1), Bina temeli (3), Kalp (1), Makinenin başlangıç düğmesi (1), Bilgisayar } \\
\text { anakartı (1), Güneş (1), Orman (1), Beyin (1) }\end{array}$ & 39 & 28 \\
\hline Sağladığı Fayda & $\begin{array}{l}\text { Odun (1), Kişisel gelişim kitabı (1), Mum (1), Köprü (1), Baba (3), Domates (1), } \\
\text { Lpg'li araç (1), Güneş (2), Çınar (1), Hastanenin temel taşı (1), Çoban (1), Hesap } \\
\text { makinesi (1), C vitamini (1), Atmosfer (1), Sokakları kaplayan çiçek yaprakları } \\
\text { (1), Ağaç (1), Şark1 (1), Ev hanımı (1), Tuz (1), Gül (1), Ev işleri (1), Arı (2), } \\
\text { Anahtar (1), Kurtarıcı (1), İlaç (1), Işı (1), Ceket (1) }\end{array}$ & 31 & 27 \\
\hline Yönetsel Unsurlar & $\begin{array}{l}\text { Yapı taşı (1), Aile reisi (1), SAS komandosu (1), Göz (1), Horoz (2), Çoban (4), } \\
\text { Ev hanımı (1), Baba (3), Anne (1), Ördek (1), Beyin (3), Bilgisayar (1), Padişah } \\
\text { (1), Hastanenin gözlüğü (1), Şemsiye (1), Pusula (1), Yük kamyonu (1), Meyve } \\
\text { ağacı (1), Yönetmen (1), Çark (1), Köy muhtarı (1), Cumhurbaşkanı (1), Telefon } \\
\text { ayarı (1), Şoför (1) }\end{array}$ & 32 & 24 \\
\hline Yönetici Nitelikleri & $\begin{array}{l}\text { Kral (1), Kral Ragnar Lothbrok (1), Anne (2), Maymun (1), Kalite (1), Teknoloji } \\
\text { (1), Aynalı cam filmi (1), Kar (1), Kitap (1), Bilgisayar (2), Oruç (1), Karınca } \\
\text { (1), Dağ (1), Telefon alarmı (1), Köpek (1), Kanguru (1), Terazi (1), Bukalemun } \\
\text { (1), Meyve (1), Çanta (1), Teknoloji (1), Robot (1), Öğrenci (1) }\end{array}$ & 25 & 23 \\
\hline Çok Yönlü Olması & $\begin{array}{l}\text { Kısır (1), Ağaç (2), Rubik küpü (1), Anne (1), Nar (1), Ahtapot (3), Bilgisayar } \\
\text { (1), Araba kullanmak (1), Çanta (1), Buğday başağı (1), Benzin istasyonu (1), } \\
\text { Bukalemun (1), Bilgisayar işletimcisi (1), Kitap (1), Ağaç kökü (1) }\end{array}$ & 18 & 15 \\
\hline $\begin{array}{l}\text { Liderlik Özellikleri } \\
\text { Taşıması }\end{array}$ & $\begin{array}{l}\text { Beyin (1), Aslan (8), Kurt (1), Oymak beyi (1), Anayasa (1), Kraliçe arı (1), Mor } \\
\text { renk (1) }\end{array}$ & 14 & 7 \\
\hline
\end{tabular}

Kategori 1: Yönetsel Unsurlar Bakımından Sağlık Yöneticisi

Yönetsel özellikler kategorisi altında toplanan metaforlar incelendiğinde, Sağlık Yönetimi Bölümünde okuyan öğrencilerin zihinlerindeki sağlık yöneticisi algılarının daha çok yönetsel özellikler odaklı olduğu görülmektedir. Katılımcıların belirttikleri metaforların ortak noktasının; bir sağlık yöneticisinin yönetim fonksiyonu başta olmak üzere, planlama, kontrol etme, yol ve yön gösterme, sorumluluk sahibi olma, karar verebilme ve koordinasyon gibi yönetim konusunun asli ve önemli unsurlarına sahip olabilme gerekliliği gibi konulardan oluşmasıdır. Tablo 3 incelendiğinde bu kategoriyi temsil eden 24 metafor üretildiği ve bu metaforların 32 kişi tarafından geliştirildiği görülmektedir. Çoban metaforunun en fazla üretilen metafor olduğu, baba ve beyin metaforlarının üçer kez, horoz metaforunun iki kez üretildiği, diğer metaforların ise birer kez üretildikleri görülmektedir. Bu kategoriyi temsil 
eden metaforları üreten katılımcıların ifadelerine bakıldığında, sağlık yöneticisinin hastane içindeki sorumluluğunun fazla olmasına ve hastanenin işleyişinin ona bağlı olmasına vurgu yapıldığı görülmektedir. Aşağıda bu kategoriyi temsil eden bazı metafor örneklerine yer verilmiștir.

Sağlık Yöneticisi; SAS Komandosu gibidir; çünkü elleri kolları bağlı suya atılmış sas komandosu gibidir, her türlü kısıtlama ile yönetmeye çalışır (Katılımcı 51, E).

Sağllk Yöneticisi beyin gibidir; çünkü hastanenin işleyişinden sorumludur. Neler yapılacağına karar veren düşünen, bilen kişidir (Katılımc1 122, K).

Sağllk Yöneticisi çoban gibidir; çünkü yöneticiler de çobanlar gibi belli bir topluluğu yönetir (Katılımc1 115, $\mathrm{K})$.

Sağllk Yöneticisi baba gibidir; çünkü her şeyi üstlenir. Üzerinde çok fazla yük vardır. (Katılımc1 180, E).

Să̆llk Yöneticisi yönetmen gibidir; çünkü yaplacak şeyleri daha önceden planlar ve koordine eder (Katılımc1 180, E).

\section{Kategori 2: Yönetici Nitelikleri Açısından}

$\mathrm{Bu}$ kategori altında toplanan metaforlar incelendiğinde, sağlık yönetimi bölümünde öğrenim gören öğrencilerin sağlık yöneticisi algılarını daha çok yöneticinin özellikleri üzerinde durarak yansıttıkları görülmektedir. Katılımcılar tarafından üretilen metaforların ortak noktası; bir sağlık yöneticisinin işinin ehli olma, otoriter olma, yeniliklere ayak uydurma, sürekli öğrenme ve kendini geliştirme gibi yöneticinin sahip olması gereken özelliklerden oluşmasıdır. Tablo 3'te de görüleceği üzere, bu kategoriyi temsil eden 23 metafor üretildiği ve bu metaforların 25 kişi tarafından geliştirildiği görülmektedir. Anne ve bilgisayar metaforunun iki kez diğerlerinin ise birer kez üretildiği görülmektedir. Bu kategoriyi temsil eden metaforları üreten katılımcıların ifadelerine bakıldığında, sağlık yöneticisinin yeterli bilgi donanımına sahip olduğu, zeki olduğu, yeniliklere açık olduğu, otoriter olduğu, vicdanlı ve liyakatli olduğu gibi özelliklere değinildiği görülmektedir. Bu kategoriyi temsil eden bazı metafor örneklerine aşağıda yer verilmiştir.

Sağlık Yöneticisi; teknoloji gibidir; çünkü teknoloji sürekli gelişim göstermektedir. Bu yüzden sağllk yöneticisi sürekli yeniliklere ayak uydurmak zorundadır (Katılımc1 20, $\mathrm{K})$.

Să̆lık Yöneticisi bilgisayar gibidir; çünkü bütün bilgiyi içinde toplar (Katılımc1 105, K).

Sağllk Yöneticisi anne gibidir; çünkü bir anne evlatlarına karşı hem otoriter hem de daima şefkatli yaklaştığ gibi sağllk yöneticisi de kurumda çalışanlarına öyle yaklaşmalıdır. Bir aileyi ayakta tutabilecek temel güç olan anne gibi (Katılımc1 8, K).

Să̆lık Yöneticisi öğrenci gibidir; çünkü sürekli ögrenir ve kendini geliştirir (Katılımc1 151, K).

Să̆lık Yöneticisi terazi gibidir; çünkü să̆lık yöneticisi eşit davranır (Katılımcı 234, K).
Sağllk Yöneticisi robot gibidir; çünkü işine duygularını karıştırmaz yapabileceğinin en iyisini yapmaya odaklanmıştır. Verilen komutlar doğrultusunda işini yapar (Katılımcı 150, K).

Kategori 3: Hayati Öneme Sahip Olması Bakımından Sağl1k Yöneticisi

$\mathrm{Bu}$ kategoriye ilişkin ortaya konulan metaforlar incelendiğinde, Sağlık Yönetimi Bölümünde okuyan öğrencilerin sağlık yöneticisini hastane içinde kritik bir unsur olarak ifade ettikleri görülmektedir. $\mathrm{Bu}$ kategoride üretilen metaforların ortak özelliği, bir sağlık yöneticisinin hastane yönetimi içinde önemli görev ve sorumluluklarının olmas1, olmazsa olmaz bir konumda bulunması gibi düşüncelerden oluşmasıdır. Tablo 3 incelendiğinde, bu kategoriyi temsil eden 28 metafor üretildiği ve bu metaforların 39 kişi tarafından geliştirildiği görülmektedir. $\mathrm{Su}$ metaforunun en fazla üretilen metafor olduğu, binanın temeli metaforunun üç kez, yemek ve ağaç kökü metaforunun iki kez ve diğerlerinin ise birer kez üretildiği görülmektedir. Katılımcıların ifadelerine bakıldığında, daha çok sağlık yöneticisinin hastaneyi ayakta tutan kişi olduğu, bir hastanenin her zaman sağlık yöneticisine ihtiyacı olduğuna yani hastane için olmazsa olmaz bir konumda olduğu üzerinde durulmuştur. Ayrıca hastanenin düzeninin ve kontrolünün ona bağlı olduğuna kısacası sağlık yöneticisinin hastane için önemli bir kişi olduğuna vurgu yapıldığı görülmektedir. Aşağıda bu kategori altında toplanan bazı metafor örneklerine yer verilmiştir.

Să̆lık Yöneticisi; su gibidir; çünkü vücudumuzun her daim suya ihtiyacl vardır. Hastanelerin her daim yöneticiye ihtiyacı olduğu gibi (Katılımc1 164, K).

Sağllk Yöneticisi; yemek gibidir; çünkü nasıl insan yemek yemeden hayatını devam ettiremezse, hastanelerde sağlık yöneticisi olmadan var olamazlar (Katılımc1 19, E).

Sağlık Yöneticisi; binanın temeli gibidir; çünkü yönetici olmak bir işletmenin en alt kademesinden en üst düzeye kadar o işletmeyi ayakta tutmaktır (Katılımcı 10, K).

Sağlık Yöneticisi; puzzle parçası gibidir; çünkü o parça eksik olduğu sürece tam resim ortaya çıkmaz. Görüntüsü tamamlanmaz (Katılımc1 183, K).

Să̆lık Yöneticisi; çay gibidir; çünkü nasıl Rize çaysız düşünülemezse, hastanelerde sağlık yöneticisiz düşünülemez (Katılımcı 43, K).

Sağlık Yöneticisi; omurga gibidir; çünkü hastaneyi ayakta tutar (Kat1lımc1 78, K).

Kategori 4: Liderlik Özellikleri Taşıması Bakımından Sağllk Yöneticisi

Katılımcilar tarafindan üretilen bu kategori altındaki metaforlar incelendiğinde, sağllk yönetimi bölümü öğrencilerinin sağlık yöneticisini bir lider olarak algıladıkları görülmektedir. $\mathrm{Bu}$ kategori altında toplanan metaforların ortak özellikleri değerlendirildiğinde; sağlık yöneticisini hastanenin tek sahibi ve karar alıcısı olarak ele aldıkları görülmektedir. Tablo 3'e bakıldığında, bu kategoriyi oluşturan 7 metafor 14 kişi tarafından üretilmiştir. En fazla üretilen metaforun aslan olduğu ve diğerlerinin birer kez kullanıldı̆̆ 1 görülmektedir. Katılımcıların bu kategori 
altındaki ifadeleri değerlendirildiğinde, daha çok hastanenin hâkimiyetinin sağlık yöneticisinde olduğuna dikkat çektikleri görülmektedir. Bu kategoriye ilişkin bazı metafor örnekleri aşağıda verilmiştir.

Să̆lık Yöneticisi; aslan gibidir; çünkü hastanenin kralıdır (Katılımcı 198, K).

Sağlık Yöneticisi; kraliçe arı gibidir; çünkü arkasinda kalan bireyler ondan komut bekler, o olmazsa düzen belirlenemez karmaşa olur (Katılımcı 251, K).

Să̆lık Yöneticisi; aslan gibidir; çünkü hâkimiyeti elinde tutar (Kat1lımc1 240, E).

Să̆lık Yöneticisi; kurt gibidir; çünkü tehlikeyi önceden sezinler. Her konuda bilgilidir. Önceden sezinlediğ $i$ için bir sorunu yaşanmadan ortadan kaldırabilir (Katılımeı 70, K).

Kategori 5: Çok Yönlü Olması Bakımından Sağlık Yöneticisi

Katılımcılar tarafindan üretilen bu kategori başlığı altında yer alan metaforlara bakıldığında, Sağlık Yönetimi Bölümü öğrencilerinin sağlık yöneticisinin multidisipliner yönüne vurgu yaptıkları görülmektedir. Katılımcılar tarafından belirtilen metaforların ortak özelliklerine bakıldığında gerek sağlık yöneticisi mesleğini icra edebilmek için alınan bilgi çeşitliliği gerek hastane içinde birçok alanda sorumluluk sahibi olması, gerekse de yönetimi altında bulunan personel çeşitliliği üzerinde durulmuştur. Tablo 3 değerlendirildiğinde bu kategoriyi temsil eden 15 metaforun 18 kişi tarafından geliştirildiği görülmektedir. Ahtapot metaforunun üç kez, ağaç metaforunun iki kez diğer metaforların ise birer kez kullanıldığı görülmektedir. Bu kategori içerisinde bulunan katılımcıların ifadelerine bakıldığında daha çok hastane içinde birçok alanla ilgilenmesi gerektiği üzerinde durulduğu görülmektedir. Buna ek olarak ise sağlık yöneticisinin her türlü bilgiye sahip olması gerektiğini vurguladıkları görülmektedir. $\mathrm{Bu}$ kategoriye ilişkin bazı metafor örneklerine aşağıda yer verilmiştir.

Sağlık Yöneticisi; anne gibidir; çünkü sorumluluğu çok fazladır. Sağllk yöneticileri săglık kurumlarının her aşamasında görevlilerdir (Katılımcı 34, K).

Să̆llk Yöneticisi; kitap gibidir; çünkü her şeyden bilgi edinmesi gerekiyor (Katılımc1 245, E).

Sağlık Yöneticisi; ăgaç kökü gibidir; çünkü bütün dallar onun yönetimindedir (Kat1lımc1 258, K).

Sağlık Yöneticisi; ahtapot gibidir; çünkü her dala kolu uzanır (Katılımc1 260, E).

Să̆lık Yöneticisi; buğday başă̆ı gibidir; çünkü başağın içinde tane tane buğday yer alır. Săglık yöneticisinin de içinde çok fazla özellik yer almalı (Katılımc1 162, E).

Kategori 6: Sağladığı Fayda Bakımından Sağlı Yöneticisi

$\mathrm{Bu}$ kategoriyi ait üretilen metaforlara bakıldığında, sağlık yönetimi bölümünde öğrenim gören öğrencilerin sağlık yöneticisini hastaneye sağladı̆̆ 1 katkılar yönüyle ele aldıkları görülmektedir. $\mathrm{Bu}$ kategori altında bulunan metaforların ortak özellikleri incelendiğinde, sağllk yöneticisinin hastanenin büyümesi, gelişmesi ve kaliteli hizmet sunmasında önemli bir rol oynadığı, hastane içinde problem çözücü kişi ve hasta-çalışan iletişimini sağlayan kişi olarak algıladıkları görülmektedir. Tablo 3 incelendiğinde, bu kategoriyi oluşturan 27 metaforun 31 kişi tarafından üretildiği görülmektedir. Baba metaforunun en fazla üretildiği görülürken, güneş ve arı metaforlarının iki kez diğerlerinin ise birer $\mathrm{kez}$ üretildiği görülmektedir. $\mathrm{Bu}$ kategoride yer alan katılımcıların ifadelerine dikkat edildiğinde sağlık yöneticisini hastanenin içindeki karmaşıklığı çözerek hastane içi düzeni sağlayan, çalışanların motivasyonunu sağlayarak onları hastanenin işleri için verimli hale getiren, hastanede kaliteli hizmet sunumu için çabalayan bir kişi olarak hastaneye verdikleri faydaları vurguladıkları görülmektedir. Bu kategoriye ait bazı metafor örnekleri aşağıda verilmiştir.

Sağllk Yöneticisi; baba gibidir; çünkü hastaneyi ayakta tutmak, hastaneyi geliştirmek, güzelleştirmek bir aile ortamı gibi samimi, güvenilir, huzurlu ve sicak bir yer yapmaya çalışır (Katılımcı 39, E).

Să̆lık Yöneticisi; güneş gibidir; çünkü hastane işletmesinin her bölümüne, her çalışanına katkısı olan. Hastaneye güneş gibi doğandır yönetici (Katılımc1 99, K).

Sağlık Yöneticisi; arı gibidir; çünkü sürekli çalışır, didinir. Bazı şeyleri düzeltmek için sürekli çabalar (Katılımc1 230, K).

Sağlık Yöneticisi; hesap makinesi gibidir; çünkü sürekli çözmesi gereken problemler vardır. Nasıl hesap makinesinin tek işlevi hesap yapmaksa sağllk yöneticisi de ona sunulan problemleri çözmeye çalışır (Katılımcı 130, K).

Să̆lık Yöneticisi; şarkı gibidir; çünkü bütün notalarl bir araya getirerek onu anlaml bir şarklya dönüş̧ürmesidir. Yönetici de bütün çalışanları bir araya getirerek onların iyi işler yapmasını sağlar (Katılımc1 178, $\mathrm{K})$.

\section{Kategori 7: Mesleğin Algılanan Olumsuzlukları Bakımından Sağlık Yöneticisi}

$\mathrm{Bu}$ kategoride katılımcılar tarafindan üretilen metaforlar incelendiğinde, sağlı yönetimi bölümünde öğrenim gören öğrencilerinin olumsuz anlam içeren ifadelerinin bu kategori altında toplandığı görülmektedir. Ayrıca sağlık yöneticisi mesleğini zorlu süreci olan bir meslek olarak algıladıkları görülmektedir. Tablo 3'e göre, bu kategori altında 44 metafor üretildiği ve bu metaforların 47 kişi tarafında geliştirildiği görülmektedir. En fazla işsiz metaforunun üretildiği, amele metaforunun iki kez diğerlerinin ise birer kez üretildiği görülmektedir. $\mathrm{Bu}$ kategoriye ilişkin katılımcıların ifadelerine bakıldığında, sağlık yöneticisi mesleğini kendilerince zor olan meşakkatli ve belirsizlik içeren yönlerini vurguladıkları görülmektedir. Sağlık yönetimi öğrencilerinin daha çok sağlık yöneticisi mesleğine ilişkin atama sorununun olması üzerinde durduğu görülmektedir. Bununla birlikte iş imkânlarının kısıtlı olması ve sağlık yöneticisinin hak ettiği değeri görmemesi üzerinde durdukları da görülmektedir. Bu kategoriye ait katılımcıların ürettikleri bazı metaforlar aşağıda verilmiştir. 
Să̆lık Yöneticisi; apandis gibidir; çünkü varlı̆̆ kabul edilmiş fakat ne işe yaradı̆̆ bilinmiyor (Katılımc1 30, E).

Să̆lık Yöneticisi; karadelik gibidir; çünkü içine girince ne olacă̆ı belli değil (Katılımc1 47, E).

Sağlık Yöneticisi; işsiz gibidir; çünkü ataması yok (Kat1limc1 108, E).

Săglık Yöneticisi; balık gibidir; çünkü să̆llk yöneticisi akarsuda yol alan sonunu göremeyen bir balıktır (Katılımc1 48, E).

Să̆llk Yöneticisi; kitap gibidir; çünkü her yerde vardır, önemlidir fakat hak ettiği değeri görmemektedir (Katılımc1 146, K).

Sağllk Yöneticisi; amele gibidir; çünkü ne iş verilirse onu yapar (Katılımc1 220, E)

Kategori 8: Meslekteki Konumu Bakımından Sağl1k Yöneticisi

$\mathrm{Bu}$ kategori altında katılımcılar tarafindan üretilen metaforlar incelendiğinde, sağl1k yönetimi bölümü öğrencilerinin sağlık yöneticisini meslekteki konumu bakımından değerlendirdikleri görülmektedir. Bu kategoriyi oluşturan metaforların ortak özelliklerine bakıldığında, sağlık yöneticisi mesleğinin kolay bir şekilde elde edilememesi, mesleki konumun iyi olması için çok çalışılması gerektiği ve kişinin kendisini geliştirmesi gerektiği üzerinde durulduğu görülmektedir. Tablo 3 incelendiğinde, bu kategori altında toplanan 35 metaforun birer kez kullanılarak yine 35 kişi tarafından geliştirildiği görülmektedir. $\mathrm{Bu}$ kategoriyi temsil eden metaforları geliştiren katılımcıların ifadelerine bakıldığında, sağlık yöneticisi mesleği çok fazla göz önünde bulundurulmasa da aslında sağlık yöneticisi mesleğinin ne kadar değerli olduğunu belirttikleri görülmektedir. Ayrıca mesleki durumları bakımından olmaları gereken yerde olmadıkları ve kolay bir şekilde elde edilen bir meslek olmadığını ifade ettikleri görülmektedir. Ancak çok çalışılarak ve kişinin kendisini devamlı geliştirerek elde edilebileceğini vurguladıkları da görülmektedir. Aşağıda bu kategoriyi temsil eden bazı metafor örneklerine yer verilmiştir.

Să̆lık Yöneticisi; bebek gibidir; çünkü her an gelişmeyi bekleyen devamlı büyüyen bir meslektir. İlgi bekleyen, unutulmayl hak etmeyen bir bebek gibidir (Katılımc1 23, K).

Sağlık Yöneticisi; evin kapısı gibidir; çünkü eve girebilmek için kapıdan geçmek gerekirse sağlık yöneticisi de bir yerlere varabilmek için bir şeylerden başlaması, kapıları açması gerekir (Katılımcı 25, K).

Sağlık Yöneticisi; $\boldsymbol{k o ̈ m u ̈ r ~ g i b i d i r ; ~ c ̧ u ̈ n k u ̈ ~ i y i ~ i s ̧ l e n i r s e ~}$ değerli taş haline gelir. Iyi işlenmesine göre değer kazanır (Katılımc1 120, K).

Sağllk Yöneticisi; altın gibidir; çünkü değeri sonradan artar (Katılımc1 202, K).

Sağlık Yöneticisi; inci gibidir; çünkü ulaşılması zor ama ulaşınca da çok değerli bir meslektir (Katılımcı 243, K).

\section{Sonuç}

Sağlık yönetimi öğrencilerinin "sağlık yöneticisi” kavramına ilişkin algılarının metaforlar vasıtasıyla tespit edildiği bu araştırmada; beyin, baba, anne, çoban, ağaç gibi metaforların ön planda olduğu 216 farklı metafor geliştirilmiştir. Geliştirilen bu metaforlar araştırmacılar tarafından 8 farklı kategoride toplanarak değerlendirilmiştir. $\mathrm{Bu}$ kategoriler; yönetsel unsurlar, yönetici nitelikleri, hayati öneme sahip olması, liderlik özellikleri taşıması, çok yönlü olması, sağladığı fayda, mesleğin algılanan olumsuzlukları ve meslekteki konumu bakımından şeklindedir.

Sağlık yöneticisi kavramına yönelik birçok farklı tür ve kategoride metafor ortaya konmuştur. Üretilen en fazla metaforun (44) sağlık yönetimi mesleğinin algılanan olumsuzluklarına yönelik olması, sağlık yönetimi okuyan öğrencilerin bazılarının ileride icra edecekleri mesleğe yönelik olumsuz bir algıya sahip olduklarını göstermektedir. Öğrenciler bu durumu olumsuz kavram ve ifadelerle dile getirmişlerdir. Dolayısıyla öğrencilerin zihinlerindeki algılara bağlı olarak bu metaforların ortaya çıktığı ve bir öğrencinin gözünden sağlık yönetimi ve sağlık yöneticisi algısının gerçekliğini gözler önüne sermektedir. Bu metafor kategorisinin yüksek frekansa sahip olmasının; bölüm mezunlarının atamalarının yapılmadığı, kamu sektöründe istihdamın yetersiz oluşu ve iş tanımındaki belirsizlikler gibi sağlık yönetimi bölümü mezunlarının hak ettikleri yerde olmayışlarına yönelik görüşlerinden oluştuğu söylenebilir. Ayrıca; öğrencilerin verdikleri cevaplar üzerinde söz konusu olumsuz görüşlerin etkili olduğu düşünülmektedir.

Olumsuz metaforların yanı sıra olumlu özellikler taşıyan metaforların da geliştirildiği görülmektedir. Öğrencilerin, sağlık yöneticisinin hastaneler açısından hayati bir öneminin olduğu, çevresine birçok fayda sağladığı, çok yönlü olduğu ve liderlik özellikleri taşıdığını belirtmeleri bu mesleği icra edecek kişilerin özelliklerine dair algılarını yansıtmaktadır ve bu metaforların çeşitliliği oldukça fazladır.

Bir diğer metafor teması; sağlık yöneticisinin meslekteki konumuna dair (35) üretilen metaforları kapsamaktadır. Öğrenciler bu metaforlar ile eğitimini aldıkları mesleklerine yönelik olarak; sağlık yönetimi alanının ve sağlık yöneticisinin kıymetli yönlerine vurgu yapmışlar; çalışkanlık, gayret ve sebat ile daha iyi yerlere gelinebileceğini belirtmişlerdir.

Katılımcıların, daha çok yöneticilik nitelikleri ve yönetsel unsurlar üzerine odaklandıkları görülmüştür. $\mathrm{Bu}$ kategorilerde özellikle bir yönetici adayının taşıması gereken özellikler, planlama, kontrol, koordinasyon ve yönetsel kararların verilmesinde sağlık yöneticisinin alması gereken rol üzerine odaklanılmıştır. Ayrıca; sağlık yöneticisinin profesyonel bir meslek grubunda yer aldığ 1 , otorite sahibi olması gerektiği, öğrenme ve yenilikçilik gibi konularda kendisini geliştirebilme ve değişimlere ayak uydurabilecek niteliklere sahip olması gerektiği de yine katılımcılar tarafından odaklanılan konular arasındadır. Sağlık sektöründe ve özellikle sağlık kuruluşlarında hayati derecede bir öneme sahip olduğu da su, binanın temeli, omurga gibi metaforlar vasıtasıyla belirtilmiştir.

Tespit edilen metaforlar arasında sağlık yöneticisinin liderlik özelliği taşıdığını belirten aslan metaforunun en fazla belirtildiği sonucuna ulaşılmıştır. Sağlık yöneticisinin birçok 
mühim özelliğe sahip olarak multidisipliner bir yapıda olması gerektiğini belirten katılımcılar kitap, ahtapot, buğday başağı gibi metaforlar aracılığıyla konuya yönelik algılarını belirtmişlerdir. Katılımcılar; baba, güneş, arı gibi metaforlar aracılığıyla sağlık yöneticisinin çevresine, mesleğine ve çalıştığı kuruma sağladığı faydalara odaklanarak kaliteli bir hizmet sunumunda etkin rol oynadıklarını ifade etmişlerdir.

\section{Kaynakça}

Akan, D., Yalçın, S. \& Yıldırım, İ. (2014). Teachers' Methaphoric Impressions Related to School Manager. Elementary Education Online, 13(1), 169-179.

Altun, T. \& Camadan, F. (2013). Rehber Öğretmenlerin Rehber Öğretmen (Psikolojik Danışman) Kavramına İlişkin Algılarının Metafor Analizi Yoluyla İncelenmesi. Kastamonu Ĕ̆itim Dergisi, 21(3), 883918.

Armstrong, S. L., Davis H. S. \& Paulson, E. J. (2011). The Subjectivity Problem: Improving Triangulation Approaches in Metaphor Analysis Studies, International Journal of Qualitative Methods, 10(2), 151-163.

Aslan, Ş. \& Özata, M. (2006). Sağlık Yöneticilerinde Duygusal Zekâ Boyutlarının Cooper Sawaf Haritasıyla Araştırılması. Hacettepe Sağlık İdaresi Dergisi, 9(2), 197-222.

Ayanoğlu, Y., Abuhanoğlu, H. \& Teke, A. (2013). Sağlık Hizmetleri Yönetimi Eğitiminde Muhasebe ve Finansman Derslerinin Önemi. Iktisadi ve İdari Bilimler Dergisi, 15(1), 1-19.

Aydın, İ. H. (2006). Bir Felsefî Metafor 'Yolda Olmak'. Din Bilimleri Akademik Araştırma Dergisi, 6(3), 9-22.

Bostan, S., Kılıç, T. \& Acuner, T. (2012). Sağlıkta Dönüşüm Programının Hastaneler Üzerindeki Değişim Etkisi: Hastane Yöneticilerinin Görüşleri. Tisk Akademi, 7(14), 108- 123.

Bozkurt, G. E. (2012). Sağlık Çalışanlarının Hastane, Hasta, Kalite, Hasta Güvenliği ve Riske Bakış Açllarının Metafor Analizi İle Değerlendirilmesi. Yüksek Lisans Tezi. İzmir: Dokuz Eylül Üniversitesi.

Bulut, D. \& İşman, Ç. (2004). Muğla İli Sağlık Yöneticilerinde Kişisel Değer Analizi. Hacettepe Sağlık İdaresi Dergisi, 7(3), 277-293.

Casarett, D., Pickard, A., Fishman, J.M., et al., (2010). Can metaphors and analogies improve communication with seriously ill patients?. Journal of Palliative Medicine, 13, 255-60.

Cerit, Y. (2008). Öğretmen Kavramı İle İlgili Metaforlara İlişkin Öğrenci, Öğretmen ve Yöneticilerin Görüşleri. Türk Eğitim Bilimleri Dergisi, 6(4), 693-712.

Çetinkaya, K. S. (2014). Öğrencilerinin Kendi Mesleklerine İlişkin Algılarının Metafor Analizi İle İncelenmesi. Pamukkale Üniversitesi Ĕ̈itim Fakültesi Dergisi, (36), 137-150.
Çimen, M. (2010). Sağlık yönetimi ve sağlık yönetim eğitimi. Acıbadem Üniversitesi Sağllk Bilimleri Dergisi, 1(3), 136-139.

Dös, İ. (2010). Aday Öğretmenlerin Müfettişlik Kavramına İlişkin Metafor Algıları. Gaziantep University Journal of Social Sciences, 9(3), 607-629.

Geçit, Y. \& Gençer, G. (2011). Sınıf Öğretmenliği 1. Sınıf Öğrencilerinin Coğrafya Algılarının Metafor Yoluyla Belirlenmesi (Rize Üniversitesi Örneği). Marmara Coğrafya Dergisi, (23), 1-19.

Güneş, A. \& Fırat, M. (2016). Açık ve Uzaktan Öğrenmede Metafor Analizi Araştırmaları. Açıköğretim Uygulamaları ve Araştırmaları Dergisi, 2(3): 115-129.

Güveli, E., İpek, A. S., Atasoy, E. \& Güveli, H. (2011). Sınıf Öğretmeni Adaylarının Matematik Kavramına Yönelik Metafor Alg1lar1. Turkish Journal of Computer and Mathematics Education, 2(2), 140-159.

Hogler, R., Gross, M. A., Hartman, J. L. \& Cunliffe, A. L. (2008). Meaning in organizational communication why metaphor is the cake, not the icing. Management Communication Quarterly, 21(3), 393-412.

Jensen, D. F. (2006). Metaphors as a bridge to understanding educational and social contexts. International Journal of Qualitative Methods, 5, 1-17.

Kahyaoğlu, F., Yanık, A. \& Tengilimoğlu, D. (2013). Batı Akdeniz Bölgesi Sağlık Kurumları Yöneticilerinde Mesleki Yeterliliklerinin Belirlenmesine Yönelik Bir Çalışma. Electronic Journal of Vocational Colleges, 3(1), 15-27.

Kale, E. \& Çiçek, Ü. (2015). Hemşirelerin Kendi Mesleklerine İlişkin Metafor Algıları. Journal of Health and Nursing Management, 2(3), 142-151.

Karsavuran, S. (2014a). Sağlık Sektöründe Mobbing: Hastane Yöneticileri Üzerinde Bir Uygulama. Mustafa Kemal Üniversitesi Sosyal Bilimler Enstitüsü Dergisi, 11(26), 271-296.

Karsavuran, S. (2014b). Sağlık Sektöründe Tükenmişlik: Ankara'daki Sağlık Bakanlığı Hastaneleri Yöneticilerinin Tükenmişlik Düzeyleri. Hacettepe Üniversitesi İktisadi ve İdari Bilimler Fakültesi Dergisi, 32(2), 133-165.

Koç, M. (2013). Student teachers' conceptions of technology: a metaphor analysis, Computers and Education, 68, 1-8.

Krieger, J. L., Parrott, R. L. \& Nussbaum, J. F. (2011). Metaphor use and health literacy: a pilot study of strategies to explain randomization in cancer clinical trials. Journal of Health Communication, 16(1), 3-16.

Lakoff G. \& Johnsen M. (2003). Metaphors we live by. London: The University Of Chicago Press.

Levitt, H., Korman, Y. \& Angus, L. (2000). 'A metaphor analysis in treatments of depression: metaphor as a marker of change', Counselling Psychology Quarterly, $13,23-35$. 
Mayring, P. (2011), Nitel Sosyal Araştırmaya Giriş, (Çev. A. Gümüş ve M. S. Durgun), 1. Baskı, Ankara: BilgeSu Yayınlar1.

Magaña, D. \& Matlock, T. (2018). How Spanish speakers use metaphor to describe their experiences with cancer, Discourse \& Communication, 1-8.

Nikinitina, L. \& Furuoka, F. (2008). “A language teacher is like..." examining malaysian students' perceptions of language teachers trough metaphor analysis. Electronic Journal of Foreign Language Teaching, 5(2), 192-205.

Öztürk, A., Tolga, Y., Şenol, V. \& Günay, O. (2008). Kayseri İlinde Görev Yapan Sağlık İdarecilerinin Tükenmişlik Düzeylerinin Değerlendirilmesi. Erciyes Tip Dergisi, 30(2), 92-99.

Öztürk, Z. \& Ilıman, E. Z. (2015). Sağlık Yönetimi ve İşletmeciliği Bölümünde Okuyan Öğrencilerin Bölümü Tercih Nedenleri İle Beklenti ve Motivasyon Düzeyleri Üzerine Bir Araştırma. Hitit Üniversitesi Sosyal Bilimler Enstitüsü Dergisi, 8(1), 71-93.

Polkinghorne, D. E. (1989). Phenomenological Research Methods, in R.S. Valle and S. Halling (Ed.), Existential-Phenomenological Perspectives in Psychology: Exploring the Breadth of Human Experience, (p. 41-60), New York: Plenum Press.

Saban, A. (2008). Primary School Teachers' and their students' mental images about the concept of knowledge. Elementary Education Online, 7(2), 421455 .

Saban, A. (2009). Öğretmen Adaylarının Öğrenci Kavramına İlişkin Sahip Oldukları Zihinsel İmgeler. Türk Eğitim Bilimleri Dergisi, 7(2), 281-326.

Saban, A., Koçbeker, B. N. \& Saban, A. (2007). Prospective teachers' conceptions of teaching and learning revealed through metaphor analysis. Teaching and Teacher Education, 17, 123-139.

Sairanen, I. (2015), Metaphors in health communication between nurse and patient. Jyväskylän Ammattikorkeakoulu Jamk University of Applied Sciences, Degree Programme in Nursing.

Stierand, M. B., Boje, D. M., Feuls, M., Haley, U. C. \& Dörflerd, V. (2016). Tstiowards a theory of organizational constraints on entrepreneurship, play, and creativity. Paper presented at British Academy of Management, Newcastle upon Tyne, United Kingdom.

Şener, E., Erdem, R. \& Akçakanat, T. (2010). Türkiye'de Lisans Düzeyinde Sağlık Yöneticisi Yetiştiren Kurumların Akademik ve Eğitsel Profili. Hacettepe Să̆lık İdaresi Dergisi, 13(1), 29-44.

Tortop, H. S. (2013). Öğretmen Adaylarının Üniversite Hocası Hakkındaki Metaforları ve Bir Değerlendirme Aracı Olarak Metafor. Yüksekögretim ve Bilim Dergisi, 3(2), 153-160

Wittink, J. (2011). Reliable metaphor analysis in organizational research. Conference Proceedings from Conference on Organizational Knowledge and Learning Capabilities.

Woodside, J. M. (2018), Organizational health management through metaphor: a mission-based approach. Journal of Health Organization and Management, 32(3), 374393.

Yıldırım, K. (2010), Nitel Araştırmalarda Niteliği Artırma. Ilkögretim Online, 9(1), 79-92.

YÖK Lisans Atlas1, https://yokatlas.yok.gov.tr/lisansanasayfa.php (Erişim: 26.07.2018).

YÖK Ön Lisans Atlas1, https://yokatlas.yok.gov.tr/onlisansanasayfa.php (Erişim: 26.07. 2018). 